\title{
Palaeocene-Eocene carbon isotopic excursion from the shallow-marine-carbonate sequence of northeast India: Implications on the CIE magnitude and geometry
}

\author{
Sruthi P Sreenivasan ${ }^{1}$, Melinda Kumar Bera ${ }^{1, *}{ }_{(\mathbb{D})}$, Arpita Samanta ${ }^{2}$ \\ and RAVIKANT VADLAMANI ${ }^{1}$ \\ ${ }^{1}$ Department of Geology and Geophysics, Indian Institute of Technology, Kharagpur 721 302, India. \\ ${ }^{2}$ Department of Geology, Asutosh College, Kolkata 700 026, India. \\ *Corresponding author.e-mail: melinda_bera@yahoo.com,melinda@gg.ittkgp.ac.in
}

MS received 12 October 2017; revised 4 March 2018; accepted 5 March 2018; published online 27 September 2018

The exact magnitude of the carbon isotopic excursion (CIE) for the Palaeocene-Eocene Thermal Maximum (PETM) is essential for our understanding of the carbon cycle perturbation. Global compilation of the PETM CIE magnitudes indicates that the shallow-marine inorganic carbonate could be a potential candidate to decipher the actual CIE magnitude. The present study, therefore, made an attempt to explore the thick Palaeogene shallow-marine carbonate sequence of the Sylhet Limestone exposed in the Jaintia Hills of northeast (NE) India, in terms of the preservation and magnitude of the PETM CIE. Exploratory sampling carried out across the Sylhet Limestone suggests that this sequence was deposited during the Late Palaeocene and Early Eocene, as evident from the age-diagnostic foraminifera. The observed $\sim 3.4 \%$ CIE at the top of the Lakadong Limestone, resting above the Miscellanea miscella and Ranikothalia nuttalli foraminifera-bearing horizon, can, therefore, be correlated with the PETM CIE. Although the magnitude of the CIE from our limited data set agrees well with the global compilation, the absence of a stepped profile questions the preservation of the CIE reported elsewhere from the Tethyan sequence. Further work is needed for a better understanding of the PETM interval in NE India.

Keywords. Palaeocene-Eocene thermal maximum; carbon isotope excursion; NE India; marine carbonate; Sylhet Limestone.

\section{Introduction}

The long-term global warming trend from the Late Palaeocene to Early Eocene interval was punctuated by several short-lived hyperthermal events. The Palaeocene-Eocene Thermal Maximum (PETM) ( 55.9 Ma; Westerhold et al. 2017) is the most prominent hyperthermal event among all other recorded hyperthermal events, so far, in the Earth's Cenozoic history (Kennett and Stott 1991; Aubry 2000). Geologically instantaneous, the PETM ( $200 \mathrm{kyr}$, Röhl et al. 2007) is characterised by massive addition of ${ }^{13} \mathrm{C}$ depleted carbon to the exogenic (ocean, atmosphere and

Supplementary material pertaining to this article is available on the Journal of Earth System Science website (http://www. ias.ac.in/Journals/Journal_of_Earth_System_Science). 
biosphere) carbon pool, and recorded as a prominent negative carbon isotope excursion (CIE) in various terrestrial and marine proxy records (Dickens et al. 1995; Cui et al. 2011; McInerney and Wing 2011; DeConto et al. 2012). The magnitude of the carbon isotopic excursion (CIE), i.e., the difference between the pre-PETM and peak-PETM $\delta^{13} \mathrm{C}$ values of the proxy records being studied, is very crucial to estimate the mass and source of carbon added to the exogenic carbon cycle. Therefore, colossal effort has been made to understand the magnitude of the PETM CIE from various proxy records spanning foraminiferal carbonate, soil carbonate, tooth enamel carbonate, terrestrial organic matter, plant lipid and many more. It is evident from all of these studies that different proxy records report different magnitude of PETM CIE. While marine carbonates record a reduced PETM CIE magnitude $(\sim 2.7 \pm 1.1 \% ; n=105)$ because of the shoaling of the carbonate compensation depth (CCD) and associated carbonate dissolution, terrestrial records generally amplify the PETM CIE magnitude $(\sim 4.7 \pm 1.5 \% ; n=48$; see a comprehensive review by McInerney and Wing 2011 and Sluijs and Dickens 2012) due to enhanced precipitation or vegetation change.

Shallow-marine inorganic carbonates, deposited well above the CCD, have therefore been increasingly studied to understand the magnitude and geometry of the CIE across the PETM. In this connection, Tethyan shallow-marine carbonates have been adjudicated to be one of the best candidates to study the magnitude and pattern of the PETM CIE (Li et al. 2017; Zhang et al. 2017). During the Late Palaeocene and Early Eocene, South Tibet was located in the northern margin of the Greater Indian (figure 1, inset). The thick carbonate sequences of the Zhepure Shan Formation of South Tibet were deposited on a tropical carbonate ramp bordering the Tethyan Ocean (Willems et al. 1996; Zhang et al. 2013). So far, four PETM CIEs have been reported from the Zhepure Shan Formation and the magnitudes of the CIEs vary from section to section. One of the possible reasons for this discrepancy in the CIE magnitudes could be the alteration of the primary carbon isotopic ratio during the burial diagenesis. However, less attention has been paid to understand the burial diagenetic history of the Zhepure Shan carbonate. Compared to the sections situated in Tibet, the Indian sections are less explored even in terms of the presence of PETM. The only report of the supposed PETM comes from the Khasi Hills of South
Shillong Plateau (Prasad et al. 2006). However, in contrast to the carbonate-hosted PETM CIE from South Tibet, the PETM reported by Prasad et al. (2006) is from a siliciclastic unit (Lakadong Sandstone) overlying the Late Palaeocene carbonate (Lakadong Limestone) of the Sylhet Limestone. The present study, therefore, aims at exploring the thick Palaeocene-Eocene shallow-marine carbonates of the Sylhet Limestone exposed in the adjacent Jaintia Hills of NE India, in terms of the presence, preservation and nature of the PETM CIE.

\section{Regional geological setup}

The Shillong Plateau in NE India is an uplifted crustal block, considered to be the eastern-most extension of the Precambrian Chhotanagpur Gneissic Complex (figure 1). The sedimentary succession was deposited during the northward drift of India after its final separation from Madagascar. The whole succession is $>4 \mathrm{~km}$ thick and comprises Late Cretaceous to Pliocene marginal marine to fluvial-deltaic sediments. The succession starts with the deposition of the Upper Cretaceous Khasi Group of sediments of marginal marine to $\mathrm{flu}-$ vial origin. Overlying Palaeocene to Middle-Late Eocene, the Jaintia Group of sediments is dominated mainly by carbonates with minor sandstone intervals (figure 2). A major marine transgression event at the beginning of the Palaeocene is thought to be responsible for the deposition of the thick limestone of the Jaintia Group. This event is designated as the incursion of the Eastern Tethys based on the similar faunal assemblage reported from the Shillong Plateau area, western India, Pakistan and Tibet (Nagappa 1959; Jauhri et al. 2006; Gogoi et al. 2009). Apart from the siliciclasticdominated Early and Middle Palaeocene Langpar and Therria Formations, a major part of the Jaintia Group consists of carbonate-dominated Sylhet Limestone Formation. This is the reason why the Jaintia Group is generally called as the Sylhet Limestone. The Sylhet Limestone is further classified into Lakadong, Umlatodh and Prang Member in the order of superposition (Misra et al. 2002; Jauhri et al. 2006). Larger benthic foraminiferal assemblage suggests a Late Palaeocene deposition age for the Lakadong Member. This is followed by the deposition of the Umlatodh and Prang Member during the Early Eocene and Middle Eocene, respectively (figure 2). 


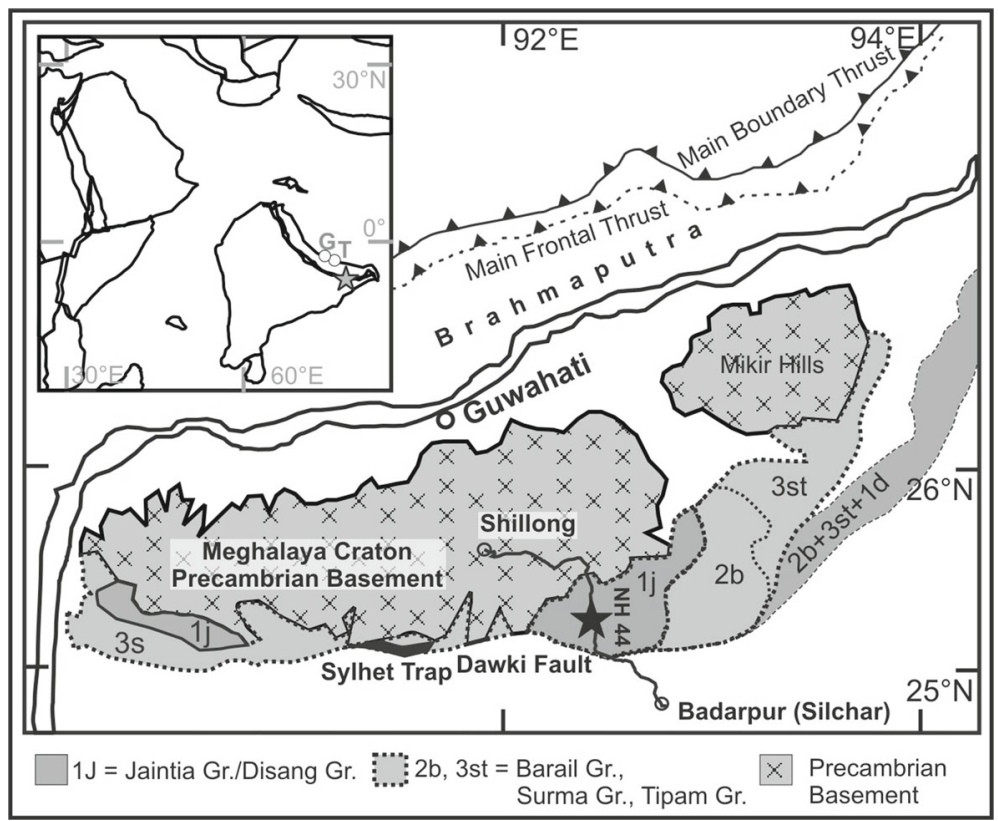

Figure 1. Figure showing the geological map of the Shillong Plateau area in NE India (simplified from maps, Geological Survey of India, 2009, 2011; Vadlamani et al. 2015). The filled star marks the study area on the National Highway 44. Inset shows the palaeolatitudinal position of the India $\sim 56 \mathrm{Ma}$ (using GPlates; Cannon et al. 2014). The filled star represents the study area and open circles represent the studied localities from Tibet where $\mathrm{G}$ and $\mathrm{T}$ represent the Gamba and Tingri, respectively.

\section{Methodology}

Excellent exposures of the Sylhet Limestone are available in limestone mines situated close to the National Highway 44. The present study was carried out in the quarry section of Star Cement. The Lakadong Sandstone crops out at the base of the quarry and the quarry section encompasses the Umlatodh Limestone. A $\sim 30 \mathrm{~m}$ drill core retrieved $\sim 3 \mathrm{~m}$ above the base of the quarry crosscuts the top of the Lakadong Limestone as well as the Lakadong Sandstone. The Lakadong Sandstone and Umlatodh Limestone have been sampled from the outcrop section of the mine, whereas the Lakadong Limestone has been sampled from the core. Lithologs were prepared by incorporating the observed grain size variations, primary sedimentary structures and faunal composition. An exploratory low resolution sampling was carried out at $\sim 5 \mathrm{~m}$ interval across the Lakadong Limestone, Lakadong Sandstone and Umlatodh Limestone for isotopic analysis. The carbonate samples were broken into two halves to expose the fresh surface. The sampling for isotopic analysis was done using a dental drill. Altered and re-crystallised carbonates as well as fossil fragments were avoided during the sampling. X-ray diffraction (XRD) analysis of the samples was performed using a Rigaku desktop X-ray diffractometer operating with $\mathrm{Cu}-\mathrm{K} \alpha$ radiation for $2 \theta$ from $15^{\circ}$ to $45^{\circ}$ at Department of Geology and Geophysics, Indian Institute of Technology, Kharagpur. After performing the XRD analysis $\sim 150-300 \mu \mathrm{g}$ of carbonate powder was analysed for its isotopic composition. All the isotope data were measured using Gas Bench (II) device attached with a Thermo DELTA-VADVANTAGE ${ }^{\circledR}$ (Thermo Fisher Scientific, Bremen, Germany) continuous flow isotope ratio mass spectrometer situated in the Department of Geology and Geophysics, Indian Institute of Technology, Kharagpur. The powdered samples were acid digested at $72^{\circ} \mathrm{C}$ by $100 \%$ orthophosphoric acid in sealed, He (99.999\%)-flushed vials. The produced $\mathrm{CO}_{2}$ then was allowed to pass successively through a Nafion tube, Valco, gas-chromatographic column to remove impurities such as moisture, nitrogen, etc. The sample gas was then introduced into the mass spectrometer through an open-split device for measurement of its isotopic ratio (Bera et al. 2010). The long-term internal reproducibility $\left(<0.1 \%\right.$ for both $\delta^{18} \mathrm{O}$ and $\left.\delta^{13} \mathrm{C}\right)$ for the Gas Bench DELTA-V-ADVANTAGE system was monitored by measuring two internal standards, i.e., Z-Carrara marble (procured from Physical Research Laboratory, Ahmedabad) and BDH 


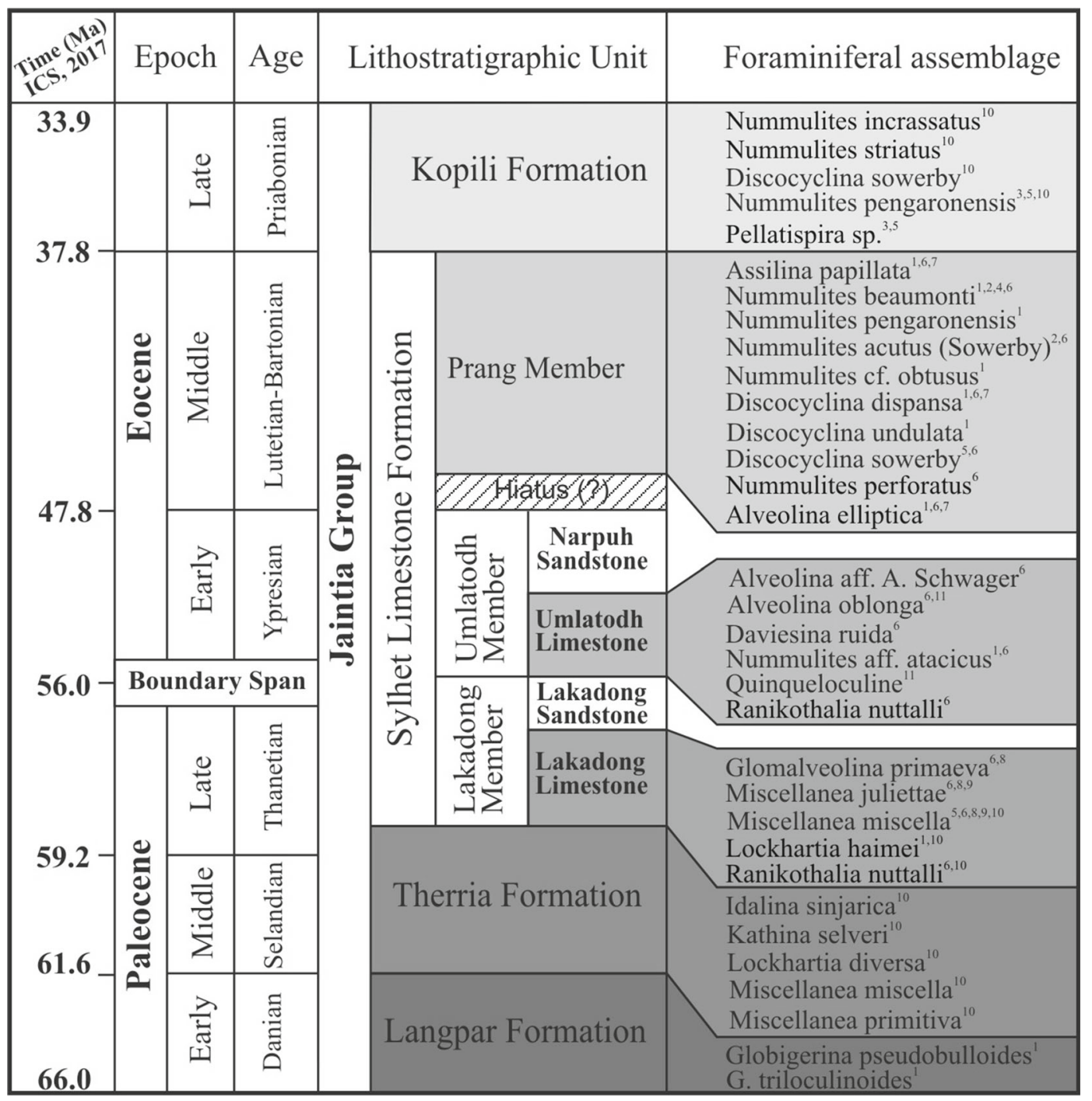

Figure 2. Generalised stratigraphy, depositional ages and foraminiferal assemblage of the Jaintia Group of rocks compiled from (1) Nagappa (1959), (2) Samanta (1968), (3) Samanta (1971), (4) Mehrotra and Banerji (1973), (5) Dutta and Jain (1980), (6) Jauhri and Agarwal (2001), (7) Misra et al. (2002), (8) Jauhri et al. (2006), (9) Gogoi et al. (2009), (10) Matsumaru and Sarma (2010) and (11) Kalita and Gogoi (2015).

(procured from University College, London). All delta $(\delta)$ values are reported in parts per thousand $(\%)$ with respect to the standard, i.e., Vienna Pee Dee Belemnite (VPDB), where $\delta$ (in $\%$ ) = $\left(R_{\text {sample }} / R_{\text {standard }}-1\right) \times 1000$ and ' $R$ ' is the ratio of the heavy-to-light isotope in the sample or standard.

\section{Results}

The lithology of the Lakadong Limestone and Umlatodh Limestone varies between the grainstone and packstone. The allochemical components are mostly dominated by biofragments. Only one sample of the Lakadong Limestone, showing oolites as a dominant allochemical component, is situated just below the Lakadong Sandstone. The Lakadong Sandstone is mainly composed of medium-to-coarse sandstone. However, there are some disperse coarse (granular)-grained lenses present all through the Lakadong Sandstone which contain fossil fragments (figure 3A). Different types of primary sedimentary structures, e.g., low-angle trough crossstratification with soft sedimentary deformation structures, gutters (figure 3B), hummocks, lensoid bed geometry, and abundant vertical burrows (figure 3C horizontal white filled arrows) were found in the Lakadong Sandstone. However, the underlying and overlying limestones are pure and devoid of any periodic/non-periodic, thick/thin siliciclastic units. Thin section of the Lakadong Limestone reveals the presence of Miscellanea 


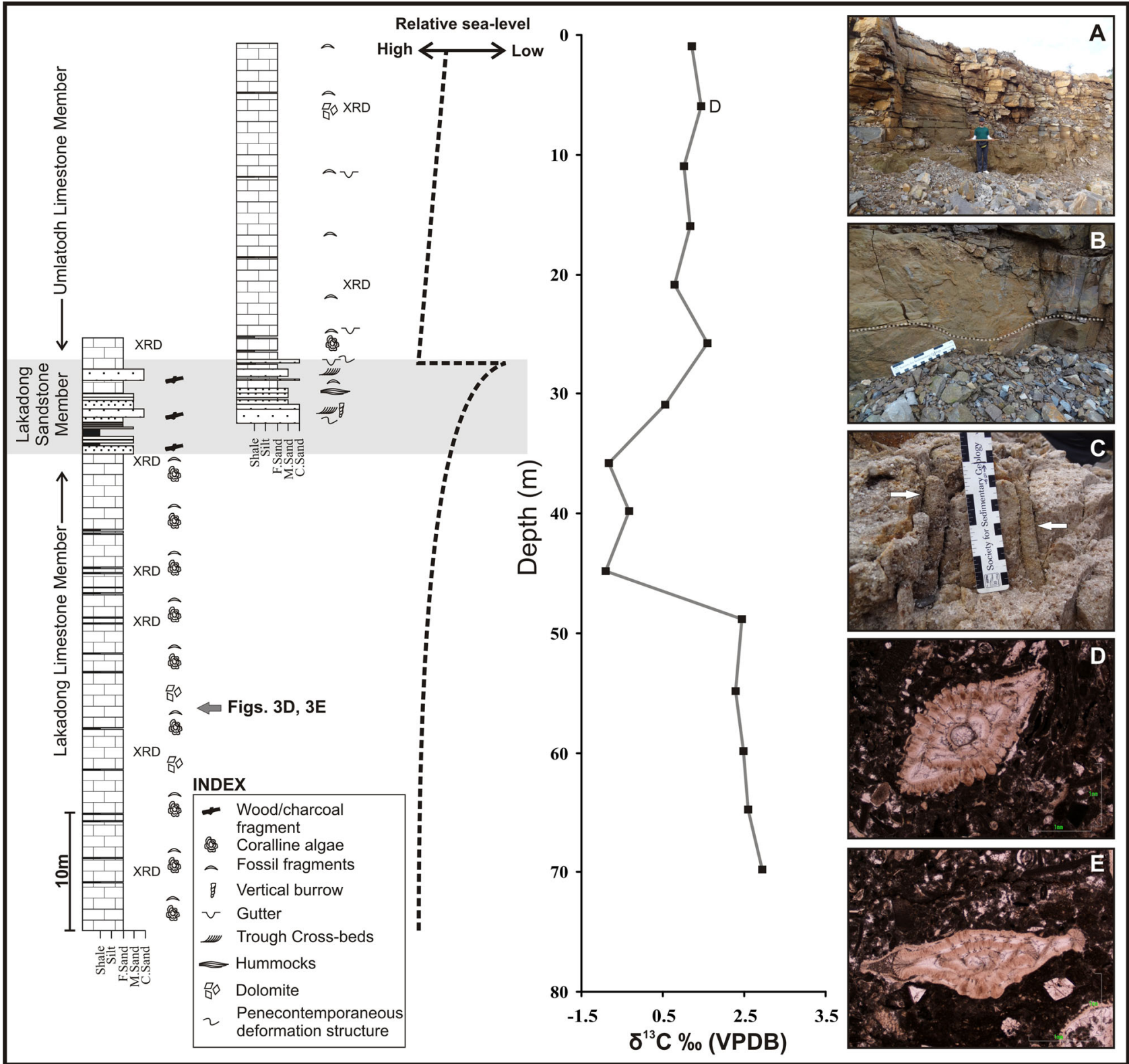

Figure 3. Representative lithologs for the core and mine-face were correlated using the stratigraphic position of the Lakadong Sandstone Member (arrow marks the stratigraphic position of the diagnostic foraminiferal fossils). A relative sea-level curve has been constructed based on the lithological change and interpretative depositional environment. Carbon isotopic ratio of the carbonate phase showing a prominent broad, negative, excursion starting within the Lakadong Limestone and ending just above the Lakadong Sandstone Member (D marks the dolomite sample). (A) Exposure of the Lakadong Sandstone Member at the base of the mine showing the lensoid bed geometry and presence of gutters (B) and vertical burrows $(\mathbf{C}$, horizontal white filled arrows). Thin section micro-photograph of the Lakadong Limestone sample showing the presence of M. miscella (d'Archiac and Haime 1853; D) and R. nuttalli (Davies 1927; E).

miscella (d'Archiac and Haime 1853; figure 3D) and Ranikothalia nuttalli (Davies 1927; figure 3E). The XRD analyses of the samples from the Lakadong Limestone $(n=5)$ and Umlatodh Limestone $(n=3)$ suggest the presence of only calcite (figure 4A) except one sample from the top of the Umlatodh Limestone which is composed entirely of dolomite.
Carbon and oxygen isotopic ratios $\left(\delta^{13} \mathrm{C}\right.$ and $\left.\delta^{18} \mathrm{O}\right)$ of all carbonate samples vary between -0.9 and $3.0 \%$ (VPDB) and -9.3 and $-4.7 \%$ (VPDB), respectively (figure 4B). Both carbon $(1.48 \%, \mathrm{VPDB})$ and oxygen $(-4.7 \%$, VPDB; uncorrected for acid fractionation factor) isotopic compositions of the only dolomite sample do not fall away from the rest of the calcite samples. 

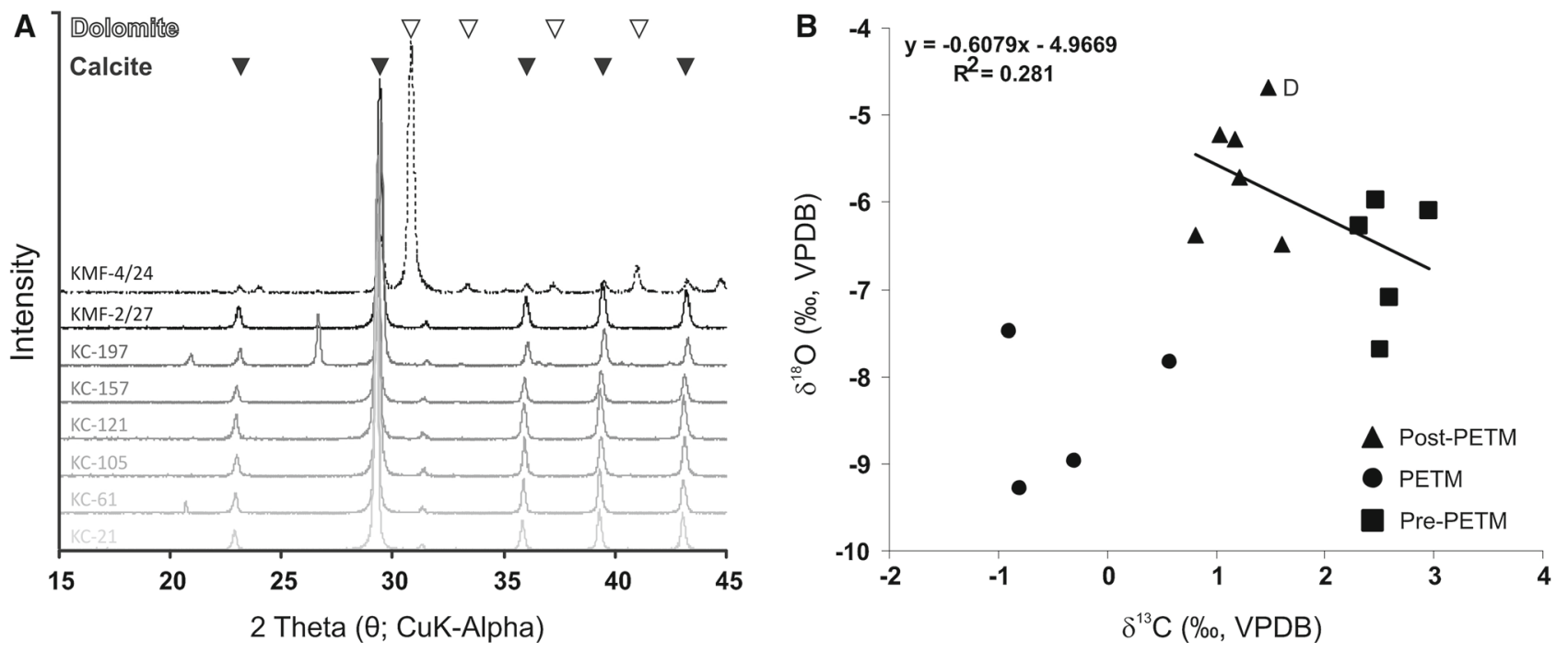

Figure 4. (A) XRD pattern showing the presence of calcite in the studied samples. Only one sample (KMF-4/24) contains dolomite (filled and open inverted triangles showing the position of pure calcite and dolomite phase, respectively). (B) The $\delta^{13} \mathrm{C}$ and $\delta^{18} \mathrm{O}$ cross-plot of the studied samples (D marks the isotopic composition of the only dolomite sample) showing crude negative correlation when only background data i.e., pre-PETM and post-PETM are considered (for details see the text).

When plotted stratigraphically (against depth), the ${ }^{13} \mathrm{C}$ values of the samples show a prominent, broad, negative-excursion at the middle of the studied section, ending just above the Lakadong Sandstone (figure 3). The average $\delta^{13} \mathrm{C}$ value of the excursion samples $(-0.7 \pm 0.3 \%$, VPDB $)$ is $\sim 3.2 \%$ (VPDB) depleted in ${ }^{13} \mathrm{C}$ compared to pre-excursion $(2.6 \pm 0.2 \%$, VPDB $)$ samples. A similar trend has also been observed for the $\delta^{18} \mathrm{O}$, where the average $\delta^{18} \mathrm{O}$ of excursion samples $\left(-8.6 \pm 1.0^{\%}, \mathrm{VPDB}\right)$ is depleted in $\delta^{18} \mathrm{O}$ compared to average $\delta^{18} \mathrm{O}$ of pre-excursion $(-6.6 \pm$ $0.7 \%$, VPDB) samples.

\section{Discussion}

\subsection{Depositional environment and age}

Different types of primary sedimentary structures, i.e., low-angle trough-cross stratification with soft sedimentary deformation structures, gutters (figure 3B), lensoid bed geometry, abundant vertical burrows (figure 3C) hummocks suggest that the Lakadong Sandstone was deposited in a nearshore, marginal-marine environment. The Lakadong Limestone and Umlatodh Limestone were deposited in a shallow-marine-carbonate ramp system ( 40-80 m water depth; Hottinger 1997; Zhang et al. 2017), as evident from the presence of different types of foraminifera. In agreement with the published literature (for details see references in figure 2) and based on the presence of agediagnostic foraminifera, i.e., M. miscella (d'Archiac and Haime 1853) and R. nuttalli (Davies 1927), a Late Palaeocene depositional age has been estimated for the Lakadong Limestone. Hence, there is a distinct possibility that in the studied section, the Late Palaeocene-Early Eocene interval is present above this foraminiferal horizon. In that case, the interval will be associated with a distinct negative CIE, as has been observed globally.

\subsection{Assessments of diagenetic alteration of stable isotope data}

Carbon and oxygen isotopic ratios of carbonate are very susceptible to diagenetic alteration. Therefore, before using the temporal variations in the isotopic ratio for palaeoclimate study careful evaluation of the data is necessary. The $\delta^{13} \mathrm{C}$ and $\delta^{18} \mathrm{O}$ crossplot of all studied carbonates (including dolomite) shows an overall positive correlation and is indicative of diagenetic alteration (figure 4B; Banner and Hanson 1990; Bera et al. 2010). Since a prominent negative excursion is present in the data set (see the last paragraph of the Results section and stratigraphic plot in figure 3), the possibility exists that these excursion data points may force all the data to show an overall negative correlation. When only those data representing the background are considered (except those demarcating the excursion, i.e., 
PETM in figure 4) these display a crude negative correlation. This distinctly antipathic behaviour of a part of the data set demands detailed discussion on the possible diagenetic scenario of the samples from the studied section. Since the isotopic ratio of the diagenetic carbonate depends upon the isotopic ratio of initial/primary carbonate, the formation temperature during diagenesis, isotopic composition of the formation water and water-rock ratio, the large spread observed in both $\delta^{13} \mathrm{C}$ and $\delta^{18} \mathrm{O}$ can be explained in either ways (figure $4 \mathrm{~B}$ ): (i) primary/early diagenesis just after the deposition possibly induced by meteoric water influx, or (ii) Late diagenesis at a higher burial temperature. Below we discuss the possible effects of these processes on the primary isotopic ratio.

Since meteoric water is depleted in ${ }^{18} \mathrm{O}$, the primary carbonate always gets depleted in ${ }^{18} \mathrm{O}$ during early diagenesis (Veizer et al. 1999). The $\delta^{18} \mathrm{O}$ values of the studied carbonate (calcite) vary between -9.3 and $-5.2 \%$ (VPDB). If the Late-Palaeocene sea water $\delta^{18} \mathrm{O}$ is assumed to be $-2.0 \%$ (VPDB; Huber et al. 2003; Ivany et al. 2008) even the most ${ }^{18} \mathrm{O}$ depleted studied carbonate can be explained by assuming a precipitation temperature of $\sim 48^{\circ} \mathrm{C}$. We, therefore, can partially rule out the possibility of any major modification of carbonate $\delta^{18} \mathrm{O}$ by early diagenesis. Since the concentration of carbon is very high in carbonate compared to the meteoric water (present as bicarbonate ion), chances of alteration of the carbonate carbon isotope are further negligible (Banner and Hanson 1990; Bera et al. 2010). In agreement, the average $\delta^{13} \mathrm{C}$ value of the studied carbonate $(1.2 \pm 1.3 \%$, VPDB $)$ falls very close to the Late Palaeocene-Early Eocene foraminiferal carbonate values recorded from different Deep Sea Drilling Project-Ocean Drilling Program (DSDPODP) sites ( 1.2\% VPDB; Zachos et al. 2001). Further, late diagenetic modification of the studied carbonate can be ruled out based on the absence of any secondary porosity in the studied samples. The only diagenetic feature visible in the studied samples is the stylolite.

However, the presence of dolomite is generally indicative of early diagenesis of marine carbonate. The only dolomite sample recovered in the present study, therefore, demands some additional discussion on the possible diagenetic environment of the studied section. When precipitated together, the dolomite gets enriched in ${ }^{18} \mathrm{O}$ by $\sim 2.6 \%$ (VPDB; Vasconcelos et al. 2005) than the coexisting calcite. Further, the $\mathrm{CO}_{2}$ produced from dolomite (by the orthophosphoric acid reaction at $72^{\circ} \mathrm{C}$ using the Gas-Bench device) is enriched by $\sim 1.2 \%$ relative to calcite (Rosenbaum and Sheppard 1986; Kim et al. 2007). We, therefore, assumed that the only dolomite in the studied section was precipitated either from $\sim 3.8 \%$ (VPDB) ${ }^{18} \mathrm{O}$ depleted water (i.e., meteoric water) during early diagenesis or at a higher temperature $\left(\sim 15^{\circ} \mathrm{C}\right.$; assuming a $0.25 \% /{ }^{\circ} \mathrm{C}$ temperaturedependent fractionation of ${ }^{18} \mathrm{O}$ between the calcite and water; Friedman and O'Neil 1977) during the late burial diagenesis. Interestingly, $\delta^{13} \mathrm{C}$ of the dolomite $(1.5 \%, \mathrm{VPBD})$ is almost identical to the rest of the calcite $(1.2 \pm 1.3 \%$, VPDB). Therefore, it is evident from the data that despite diagenetic alteration (possibly partial), at selected stratigraphic levels, the $\delta^{13} \mathrm{C}$ of the studied carbonates still preserve its original isotopic composition and can be used for the palaeoclimate study.

\subsection{CIE magnitude and geometry}

Temporal evolution of $\delta^{13} \mathrm{C}$ of the studied carbonates shows a large, prominent, negative excursion in the middle of the Lakadong Limestone. Resting above the stratigraphic occurrence (marked by grey filled arrow in figure 3) of two Late Palaeocene larger benthic foraminifera, i.e., M. miscella (d'Archiac and Haime 1853) and $R$. nuttalli (Davies 1927), this large $\sim 3.4 \%$ excursion can be correlated with the global CIE associated with the PETM. Although this finding agrees well with the earlier published biostratigraphic zonation of the Lakadong Limestone and overlying Umlatodh Limestone (figure 2), there is a strong disagreement with the only published record of the supposed PETM within the Lakadong Sandstone from the adjacent Khasi Hills of South Shillong Plateau (Prasad et al. 2006). It is important to mention that apart from the stratigraphic position of the PETM interval, the thickness of the limestone and sandstone members vary considerably across the basin. One possible explanation for this discrepancy could be the time transgressive nature of the facies boundaries across the basin, among others.

When compared with the published global carbon isotopic record, the magnitude of the PETM CIE $(\sim 3.4 \%$, VPDB) from the Lakadong Limestone is slightly larger than the average global carbonate record $(\sim 2.7 \pm 1.1 \%$, VPDB; figure 5$)$ 


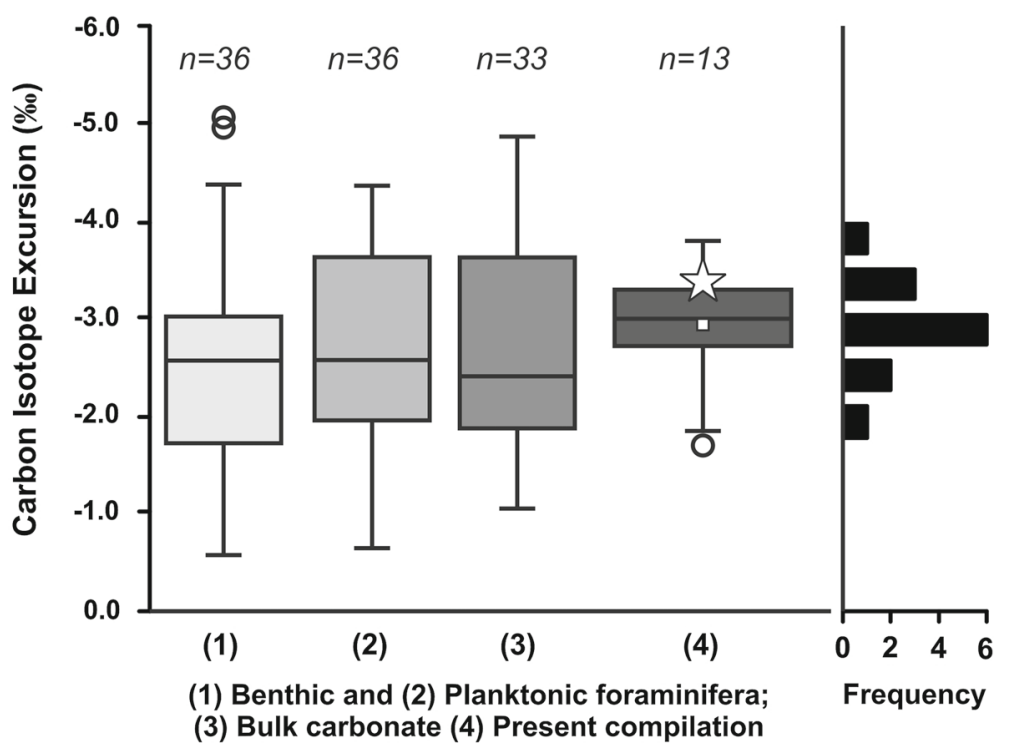

Figure 5. Figure showing the Box-and-Whisker plot of the published CIE magnitudes (1) benthic foraminifera, (2) Planktonic foraminifera and (3) bulk carbonate from McInerney and Wing (2011). The present compilation (4) is also shown where square marks the average CIE magnitude. Circles represent outliers. The open star represents the PETM CIE magnitude reported from the NE carbonate. Frequency distribution of the compiled data for $0.5 \%$ bins is also shown in a frequency plot in the right panel.

compiled by McInerney and Wing (2011). McInerney and Wing (2011) classified their carbonate data into three broad categories, i.e., benthic foraminiferas, planktonic foraminiferas and bulk carbonates (figure 5). As discussed earlier, foraminiferal carbonate records show extensive dissolution because of the shoaling of the CCD and register a lower CIE magnitude. It is, therefore, increasingly being felt that the shallowmarine inorganic carbonate could possibly record the actual CIE magnitude. However, when compiling the data, McInerney and Wing (2011) incorporated all inorganic carbonate CIE values from the published literature $(n=33)$ without any careful evaluation of the primary data. In the present study, we found that many of the data reported in these 33 primary references are inappropriate due to the following reasons. In many of the studied sections, the PETM onset is marked by different lithologies, where chances are there that different porosity and different water-rock ratio in these different lithologies will drive diagenesis of the primary carbonate in different ways, therefore resulting in either reduction or amplification of the CIE magnitude. Even some original references are taken from foraminiferal carbonate data. Moreover, there were some repetitions. We, therefore, carefully evaluated the existing compilation and added few new and missed references to the PETM CIE magnitude dataset. Our new compilation consists of only 13 clean data where both the PETM onsets and CIEs are present within the same lithology (figure 5; Supplementary material). The new average CIE magnitude $\sim 2.9 \pm 0.6 \%$ (VPDB) from the inorganic shallowmarine carbonate agrees well with the present CIE magnitude of $3.4 \%$ (VPDB). However, it is lower than that of the maximum reported CIE magnitude of $3.8 \%$ (VPDB) from the shallow-marine carbonate (Höntzsch et al. 2011) and generally accepted atmospheric $\mathrm{CO}_{2} \mathrm{CIE}$ of $\sim 4.5^{\circ} \%$ (VPDB) (Diefendorf et al. 2010). High-resolution sampling of the PETM interval and more careful evaluation of the isotopic values for the diagenetic phases are necessary to find the exact CIE magnitude for this PETM from the NE section.

A recent study from the Tethyan shallow-marine carbonate from the Tingri area showed complete preservation of the CIE but with the unusually high magnitude of $\sim 7 \%$ (Zhang et al. 2017) and a prominent stepped profile. Along with the CIE thickness, the presence of this stepped CIE profile has been put forward in support for the complete and true (unaltered) preservation of the PETM CIE profile. When comparing the thickness of the PETM CIE for the preservation, both the sections show comparable thickness wherein the NE carbonates display $\sim 18 \mathrm{~m}$ thick CIE and the Tingri carbonates record a $\sim 17 \mathrm{~m}$ thick CIE interval. Furthermore, the presence of the oolite-bearing carbonate at the top of the Lakadong limestone indicates minimal wave-induced erosion of the 
Lakadong Limestone by overlying the Lakadong Sandstone. Therefore, in terms of preservation of the CIE profile, both these sections record complete preservation of the CIE profile. However, in contrast to what observed in the Tingri carbonate, the present dataset, although limited, does not show any stepped CIE profile. Most importantly, the successive depletion in $\delta^{13} \mathrm{C}$ of the carbonate within the Tingri PETM CIE body starting at step c (onset) and all through the PETM main body up to step g (beginning of the recovery, see figure 8 of Zhang et al. 2017) has not been found in the present section. The possibility exists that these Tingri nodular carbonates suffered considerable diagenetic modification as proposed by the recent study focusing on the detailed field, microfacies and stable isotopic observation (Kahsnitz and Willems 2017). In contrast to the Tingri area, PETM CIE in NE India has been arrested in a monotonous grainstone and packstone lithology, and therein exists the possibility that this section would have faithfully recorded the actual geometry of the PETM CIE. Further, high-resolution multi-proxy isotopic analyses are needed for a better understanding of the PETM CIE magnitude and the CIE geometry in this section.

\section{Conclusions}

Sedimentological studies carried out across the Lakadong Limestone, Lakadong Sandstone and Umlatodh Limestone Member of Sylhet Limestone Formation suggests that this sequence was deposited in the shallow ( $40-80$ m water depth)marine setup. While larger benthic foraminiferabearing grainstone and packstone lithology of the Lakadong Limestone and Umlatodh Limestone indicate that these units were deposited in a carbonate ramp settings, overall sandy lithology and primary sedimentary structures, i.e., lowangle trough-cross stratification with soft sedimentary deformation structures, gutters (figure 3B), lensoid bed geometry, abundant vertical burrows (figure 3C) and hummocks suggest that the Lakadong Sandstone was deposited in a mixed siliciclastic carbonate near-shore environment. The presence of age-diagnostic foraminifera, i.e., $M$. miscella (d'Archiac and Haime 1853) and R. nuttalli (Davies 1927) at the middle part suggests a possible Late Palaeocene depositional age for the Lakadong Limestone Member. Careful evaluation of the diagenetic condition, using combined thin section petrography, XRD and stable isotopic analysis, reveals that despite early and possibly late burial diagenesis at the selected stratigraphic interval, the carbonate preserves its original carbon isotopic composition and is suitable for palaeoclimate study. The only large negative CIE of $\sim 3.4 \%$ (VPDB) occurring above the M. miscella- and $R$. nuttalli-bearing horizon can, therefore, be correlated with the globally reported CIE associated with the PETM. Although the magnitude of the excursion from our limited data set agrees well with the global compilation, it strongly differs from the earlier reported magnitude and geometry from the Tethyan shallow-marine carbonate by previous workers. As has been suggested by the recent study, the unusually large magnitude and geometry of the Tethyan CIE is possibly an artefact of diagenetic alteration (Kahsnitz and Willems 2017). While Tethyan nodular-shaley carbonates suffered extensive diagenetic modification by percolating meteoric fluids, thereby altering its carbon isotopic composition, NE grainstone/packstone carbonate lithology suffered minimal diagenetic modification possibly due to the early cementation. Further, high resolution and detailed isotopic work are needed for a better understanding of the PETM interval from this NE section.

\section{Acknowledgements}

MKB thanks IIT Kharagpur for funding the fieldwork through its Professional Development Fund. This work forms part of the Ph.D. thesis of SPS, who thanks the Council of Scientific and Industrial Research (CSIR), New Delhi, for the fellowship. We thank IIT Kharagpur for funding the Stable Isotope Analytical Facility through its Diamond Jubilee Laboratories Grant where all isotope data used in this work were generated. The paper is a result of a pre-decision effort in connection with a prospective research grant proposal on identifiable PETM section in the Jaintia Hills for submission to MoES. The authors acknowledge the help extended by the Star Cement authority, particularly by $\mathrm{H} \mathrm{R}$ Singh and A J Singh.

\section{References}

Aubry M P 2000 Where should the global stratotype section and point (GSSP) for the Paleocene/Eocene boundary be located?; B. Soc. Geol. Fr. 171 461-476.

Banner J L and Hanson G N 1990 Calculation of simultaneous isotopic and trace element variations during 
water-rock interaction with applications to carbonate diagenesis; Geochim. Cosmochim. Acta 54 3123-3137.

Bera M K, Sarkar A, Chakraborty P P, Ravikant V and Choudhury A K 2010 Forced regressive shoreface sandstone from Himalayan foreland: Implications to early Himalayan tectonic evolution; Sedim. Geol. 229 268-281.

Cannon J, Lau E and Müller R D 2014 Plate tectonic raster reconstruction in G Plates; Solid Earth 5 741-755, https://doi.org/10.5194/se-5-741-2014.

Cui Y, Kump L R, Ridgwell A J, Charles A J, Junium C K, Diefendorf A F, Freeman K H, Urban N M and Harding I C 2011 Slow release of fossil carbon during the Palaeocene-Eocene Thermal Maximum; Nat. Geosci. 4 481-485.

d'Archiac A and Haime J 1853 Description des animaux fossiles du groupe nummulitique des Indes, précédée d'un résumé géologique et d'une monographie des Nummulites; Gide \& Baudry, Paris, 373p.

Davies A M 1927 Lower Miocene Foraminifera from Pemba Island; Stockley GM Report on the Palaeontology of the Zanzibar Protectorate, pp. 7-12.

DeConto R M, Galeotti S, Pagani M, Tracy D, Schaefer K, Zhang T, Pollard D and Beerling D J 2012 Past extreme warming events linked to massive carbon release from thawing permafrost; Nature 48487.

Dickens G R, O'Neil J R, Rea D K and Owen R M 1995 Dissociation of oceanic methane hydrate as a cause of the carbon isotope excursion at the end of the Paleocene; Paleoceanography 10 965-971.

Diefendorf A F, Mueller K E, Wing S L, Koch P L and Freeman K H 2010 Global patterns in leaf ${ }^{13} \mathrm{C}$ discrimination and implications for studies of past and future climate; Proc. Nat. Acad. Sci. 107 5738-5743.

Dutta S K and Jain K P 1980 Geology and palynology of the area around Lumshnong, Jaintia Hills, Meghalaya, India; Biol. Memoirs 5(1) 56-81.

Friedman I and O'Neil J R 1977 Data of geochemistry: Compilation of stable isotope fractionation factors of geochemical interest; US Government Printing Office.

Geological Survey of India 2009 Geology and mineral resources of Assam and Meghalaya; Geol. Surv. India Misc. Publ., No. 30, Part IV, Vol. 2, (i) Assam and (ii) Meghalaya, 44p \& 46p.

Geological Survey of India 2011 Geology and mineral resources of Manipur, Mizoram, Nagaland and Tripura; Geol. Surv. India Misc. Publ., No. 30, Part IV, Vol. 1 (Part 2), 96p.

Gogoi B, Deka Kalita K, Garg R and Borgohain R 2009 Foraminiferal biostratigraphy and palaeoenvironment of the Lakadong Limestone of the Mawsynram area, South Shillong Plateau, Meghalaya; J. Palaeontol. Soc. India $\mathbf{5 4}$ 209-224.

Höntzsch S, Scheibner C, Kuss J, Marzouk A M and Rasser M W 2011 Tectonically driven carbonate ramp evolution at the southern Tethyan shelf: The Lower Eocene succession of the Galala Mountains, Egypt; Facies 57 51-72.

Hottinger L 1997 Shallow benthic foraminiferal assemblages as signals for depth of their deposition and their limitations; B. Soc. Geol. 168 491-505.

Huber M, Sloan L and Shellito C 2003 Early Paleogene oceans and climate: A fully coupled modelling approach using the NCAR CCSM; In: Causes and consequences of globally warm climates in the Early Paleogene (eds) Wing S L, Gingerich P D, Schmitz B and Thomas E, Boulder Colorado Geol. Soc. Am. Spec. Paper 369 2547.

Ivany L C, Lohmann K C, Hasiuk F, Blake D B, Glass A, Aronson R B and Moody R M 2008 Eocene climate record of a high southern latitude continental shelf: Seymour Island, Antarctica; Geol. Soc. Am. Bull. 120659 678.

Jauhri A K and Agarwal K K 2001 Early Palaeogene in the south Shillong Plateau, NE India: Local biostratigraphic signals of global tectonic and oceanic changes; Palaeogeogr. Palaeoclimatol. Palaeoecol. 168 187-203.

Jauhri A K, Misra P K, Kishore S and Singh S K 2006 Larger foraminiferal and calcareous algal facies in the Lakadong Formation of the South Shillong Plateau, NE India; J. Palaeontol. Soc. India 51 51-61.

Kahsnitz M M and Willems H 2017 Genesis of Paleocene and Lower Eocene shallow-water nodular limestone of South Tibet (China); Carbonate Evaporate, https://doi.org/10. 1007/s13146-017-0360-7.

Kalita K D and Gogoi H 2015 Microfacies types (MFT) and palaeoenvironment of the Umlatodh carbonates in the Shillong Plateau of Meghalaya, NE India; J. Geol. Soc. India 85 686-696.

Kennett J P and Stott L D 1991 Abrupt deep sea warming, paleooceanographic changes and benthic extinctions at the end of the Paleocene; Nature 353225 229.

Kim S T, Mucci A and Taylor B E 2007 Phosphoric acid fractionation factors for calcite and aragonite between 25 and $75^{\circ} \mathrm{C}$ : revisited; Chem. Geol. 246 135-146.

Li J, Hu X, Garzanti E and BouDagher-Fadel M 2017 Shallow-water carbonate responses to the PaleoceneEocene thermal maximum in the Tethyan Himalaya (southern Tibet): Tectonic and climatic implications; Palaeogeogr. Palaeoclimatol. Palaeoecol. $466 \quad 153-$ 165.

Matsumaru K and Sarma A 2010 Larger foraminiferal bio-stratigraphy of the lower Tertiary of Jaintia Hills, Meghalaya, NE India; Micropaleontology $\mathbf{5 6} \quad 539$ 565 .

McInerney F A and Wing S L 2011 The Paleocene-Eocene Thermal Maximum: A perturbation of carbon cycle, climate, and biosphere with implications for the future; Ann. Rev. Earth. Plan. Sci. 39 489-516.

Mehrotra K K and Banerji R K 1973 Middle-upper Eocene biostratigraphy of Khasi and Jaintia Hills based on planktonic and larger foraminifera; J. Palaeontol. Soc. India 18 $22-26$.

Misra P K, Jauhri A K, Kishore S and Singh S K 2002 Calcareous algae from the Lakadong Formation of the south Shillong Plateau; Rev. Paleobiol. 21 717-734.

Nagappa Y 1959 Foraminiferal biostratigraphy of the cretaceous: Eocene succession in the India-Pakistan-Burma region; Micropaleontology 5 145-192.

Prasad V A, Garg R A, Khowaja-Ateequzzaman S I and Joachimski M 2006 Apectodinium acme and the palynofacies characteristics in the latest Palaeoceneearliest Eocene of northeastern India: Biotic response to Palaeocene-Eocene thermal maxima (PETM) in low latitude; J. Palaeontol. Soc. India 51 75-91. 
Röhl U, Westerhold T, Bralower T J and Zachos J C 2007 On the duration of the Paleocene-Eocene thermal maximum (PETM); Geochem. Geophys. Geosyst. 8 1-13.

Rosenbaum J and Sheppard S M 1986 An isotopic study of siderites, dolomites and ankerites at high temperatures; Geochim. Cosmochim. Acta 50 1147-1150.

Samanta B K 1968 Nummulites (foraminifera) from the Upper Eocene Kopili Formation of Assam, India; Palaeontology 11 669-682.

Samanta B K 1971 Early Tertiary stratigraphy of the area around Garampani, Mikir-north Cachar hills, Assam; Geol. Soc. India 12 318-327.

Sluijs A and Dickens G R 2012 Assessing offsets between the $\delta^{13} \mathrm{C}$ of sedimentary components and the global exogenic carbon pool across early Paleogene carbon cycle perturbations; Global Biogeochem. Cy. 26 1-14.

Vadlamani R, Wu F Y and Ji W Q 2015 Detrital zircon U-Pb age and Hf isotopic composition from foreland sediments of the Assam Basin, NE India: Constraints on sediment provenance and tectonics of the Eastern Himalaya; $J$. Asian. Earth. Sci. 111 254-267.

Vasconcelos C, McKenzie J A, Warthmann R and Bernasconi S M 2005 Calibration of the $\delta^{18} \mathrm{O}$ paleothermometer for dolomite precipitated in microbial cultures and natural environments; Geology 33 317-320.

Corresponding editor: PARTha Pratim Chakraborty
Veizer J, Ala D, Azmy K, Bruckschen P, Buhl D, Bruhn F, Carden G A, Diener A, Ebneth S, Godderis Y and Jasper $\mathrm{T} 1999^{87} \mathrm{Sr} /{ }^{86} \mathrm{Sr}, \delta^{13} \mathrm{C}$ and $\delta^{18} \mathrm{O}$ evolution of Phanerozoic seawater; Chem. Geol. 161 59-88.

Westerhold T, Röhl U, Wilkens R, Gingerich P D, Clyde W, Wing S, Bowen G and Kraus M 2017 Synchronizing early Eocene deep-sea and continental records - New cyclostratigraphic age models from the Bighorn Basin Coring Project; Clim. Past Discuss., https://doi.org/10. 5194/cp-2017-74.

Willems H, Zhou Z, Zhang B G and Gräfe K U 1996 Stratigraphy of the Upper Cretaceous and lower Tertiary strata in the Tethyan Himalayas of Tibet (Tingri area, China); Geol. Rundsch. 85 723-754.

Zachos J, Pagani M, Sloan L, Thomas E and Billups K 2001 Trends, rhythms, and aberrations in global climate $65 \mathrm{Ma}$ to present; Science 292 686-693.

Zhang Q, Willems H and Ding L 2013 Evolution of the Paleocene-Early Eocene larger benthic foraminifera in the Tethyan Himalaya of Tibet, China; Int. J. Earth. Sci. 102 1427-1445.

Zhang Q, Wendler I, Xu X, Willems H and Ding L 2017 Structure and magnitude of the carbon isotope excursion during the Paleocene-Eocene thermal maximum; Gondwana. Res. 46 114-123. 